\title{
Corruption, Endogenous Fertility, and Growth
}

\section{Matthias Cinyabuguma*}

\begin{abstract}
While much research in economic development has pointed out the negative impact of corruption on growth, less research has been devoted to studying the relationship between corruption and demographic transition. This theme is developed into an overlapping generation model in which corruption affects fertility decisions through its negative impact on physical capital formation and its productivity. The analysis indicates that, when the level of corruption is high, the productivity of capital is low and fertility is excessively high because of the relatively low cost of raising children. Theoretical and empirical results show that, in both developed and developing countries, corruption creates distortions and leads to low-equilibrium traps. Introducing child quality into the model accelerates the pace of demographic transition and produces effects similar to reducing the level of corruption. Empirical estimates confirm the predictions of the model and support the proposition that fertility declines in less corrupt countries.
\end{abstract}

Keywords: Endogenous fertility, corruption, productivity of physical capital, economic growth.

JEL Classification: J13, 016, 012, F43.

\section{Introduction}

Since the work of Shleifer and Vishny (1993) and Mauro (1995), the relationship between corruption and economic development has become a central question in both economic theory and empirical work. Many authors have studied the concept of corruption in terms of bad policies or inefficient institutions (see, for instance, Djankov, LaPorta, Lopez-de-Silanes, \& Shleifer, 2002). Their work indicates that corruption negatively affects economic growth by causing various economic inefficiencies and by discouraging the accumulation of both physical and human capital. For example, in many cases, corruption has slowed down economic growth through the misallocation of resources and talents (Murphy, Shleifer, \& Vishny, 1991, 1993). A number of other authors conclude that corruption leads to lower economic growth by decreasing

\footnotetext{
*Assistant Professor of Economics, University of Maryland, Baltimore County.
} 
government revenue, which is needed to finance productive spending (see, for instance, Tanzi \& Davoodi, 1997).

Thus, much research in economic development has pointed out the negative impact of corruption on growth, but less research has been devoted to studying the relationship between corruption and demographic transition. In this article, we develop an overlapping-generations model in which corruption affects fertility decisions through its impact on physical capital accumulation and its productivity. When the level of corruption is high, the marginal productivities of capital and labor fall, and fertility is excessively high because of low childbearing costs relative to the costs of capital accumulation. Our results show that, in both developed and developing countries, corruption creates distortions and leads to lowequilibrium traps. While an economic structure with limited corruption encourages savings by citizens-and, hence, the accumulation of physical capital-countries mired in corruption are trapped in poverty with excessively high fertility. This view suggests that corruption affects economic development by deterring investments and making them less productive (da Silva, Garcia, \& Bandeira, 2000).

As noted above, there is a large body of literature studying the effects of government spending on economic growth. Most early theoretical work was motivated by the empirical work of Aschauer (1989), among others, and argued that public investment had a substantial positive effect on growth. Starting with Barro (1990), public spending was introduced into the production function to account for its impact on long-run growth. Shleifer and Vishny (1993), among others, have studied the relationship between corruption and economic growth in the presence of weak institutions, and argued strongly that corruption will be stronger where institutions are weak. ${ }^{1}$ In particular, RoseAckerman (1978) has emphasized the very nature of bureaucratic and legal institutions that are tainted by bribery and corruption.

One of the most striking aspects of economic development has been the demographic transition. Underlying this is the idea that, as an economy goes through the advanced stages of its development process, parents trade off child quantity for child quality. Existing theoretical studies attribute this outcome to particular features of economic

\footnotetext{
${ }^{1}$ A contrary strand in economic literature suggests that corruption may, in some instances, improve economic welfare (Huntington, 1968, p. 386; Leff, 1964, p. 11). In this regard, corruption induces the more efficient provision of public services, and serves as a bridge for entrepreneurs to bypass inefficient regulations. This article, however, emphasizes the adverse effects of corruption on the provision of public services.
} 
development, such as reduced child mortality (Kalemli-Ozcan, 2003; Soares, 2005); reduced income inequality (de la Croix \& Doepke, 2003); increased demand for human capital (Galor \& Weil, 2000); improved health (Murtin, 2009); and decreased need for child labor (Hazan \& Berdugo, 2002). A number of authors provide further empirical support for these arguments (Becker, Cinnirella, \& Woessmann, 2010; Black, Devereux, \& Salvanes, 2005; Bleakley \& Lange, 2009; Hanushek, 1992; Rosenzweig \& Wolpin, 1980); and some place institutions at the center of the demographic transition (Basso \& Vilalta, 2011; Wang, 2005).

Although economic historians use institutions to analyze demographic transitions, this article is, to the best of the author's knowledge, the first to directly relate public institutions (public spending), corruption, and the demographic transition. Its core finding is that, during any transition to sustained economic growth, reductions in corruption are instrumental to the onset of demographic transition.

The rest of the article is organized as follows. Section 2 presents the basic features of an overlapping generation economy and its expected performance results. Section 3 reports the model's empirical estimates, and Section 4 concludes the article.

\section{The Basic Structure of the Model}

\subsection{Environment}

We begin by positing a closed economy with overlapping generations in which economic activity extends over infinite, discrete periods of time. Each generation consists of homogeneous agents who work in the first period while being retired in the second. In other words, there are two generations-young and old-at each point in time. In the first period, individuals decide what quantity of market goods and education to invest in their children, and thus determine what number of children to have and what portion of income to save for consumption during their own retirement.

We allow for a quadratic child-rearing cost in net income to reflect the fact that time and/or parental resources devoted to raising and educating children could have been allocated to market work or leisure (Birdsall, 1988). Unlike standard models in economic development in which child-rearing time is modeled as forgone earnings, the quadratic time-cost of child rearing reflects the idea that it becomes relatively more expensive for individuals with higher incomes and greater skills. In 
particular, Becker, Murphy, and Tamura (1990), and Galor and Weil (1996) indicate that increases in parental human capital can increase the opportunity cost of parental time and lower fertility by raising the time cost of rearing a child. Each child born at time $t$ costs $z_{t}$ evaluated in terms of his parent's income net of government taxes $\tau_{t}$, with $z_{t}=$ $b\left(\left(1-\tau_{t}\right) h_{t} w_{t}\right)^{2} .{ }^{2} h_{t}$ is the level of human capital for an adult parent of period $t$, and $w_{t}$ is the wage per effective labor.

People enjoy parenthood, and children are thought of as consumption goods (Becker \& Barro, 1988). The economic viability of fertility decisions, as reflected by individual choices and the accumulation of capital, depends on the level of corruption, which affects the marginal productivity of capital and the opportunity cost of raising children. In this setting, the cost of raising a child increases when corruption decreases, and falls when corruption rises. Since corruption affects the productivity of physical capital, we conclude that the cost of raising a child will be related not only to the stock of existing physical capital, but also to its effective use.

Following Feng, Kugler, and Zak (2000) and Cinyabuguma (2011), we construct a simple household decision model in which fertility is endogenous and influenced by the opportunity cost of raising children, a parent's level of education, and the use of time and savings related to productive activities. We model corruption very simply as to affect the productivity of capital and, hence, the opportunity cost of raising children. Similar to Feng et al. (2000), the government in this model uses tax revenue to promote policies and institutions that enhance growth. However, its ability to build pro-growth institutions is adversely affected by corruption among public officials. Consequently, fewer resources are spent on public goods that support production and this, in turn, reduces the productivity of physical capital and hampers economic growth.

Since the time-cost of child rearing is defined in terms of missed opportunities, countries with lower capital productivity will have a lower opportunity cost for the time spent raising children and, hence, higher fertility. For simplicity's sake, we assume the proceeds from corruption to be deadweight loss for the economy as a whole.

\footnotetext{
${ }^{2}$ The cost of child-rearing imposes an upper limit on the maximum feasible number of children an individual can bear. For example, by making savings equal zero, the maximum number of children a parent can bear is given by $(x)^{\max }=1 / b\left(1-\tau_{t}\right) w_{t} h_{t}$. To avoid non convexity problems that might arise when making fertility decisions, we neglect integer restrictions on $x_{t}$.
} 
The next section formalizes these insights into a dynamic model in which corruption and fertility interact in the process of development.

\subsection{Individuals' Preferences}

Individuals derive utility in youth from the number of children they have, and in old age from consumption. This can be summarized by the following utility function:

$$
U=\ln x_{t}+\beta \ln c_{t+1}
$$

Where $x_{t}$ is the effective number of children born (preferences are shaped by the level of corruption); $\beta$ is the parameter for time preference; and, $c_{t+1}$ is the old age consumption for a member of generation $t$. We assume that there is no consumption in the first period of life, and that individuals consume only during their second period of life, i.e. when retired. ${ }^{3}$ We further, assume that all goods are perishable, and that the only means of transferring value across periods of life is capital markets. As it will become apparent in this model, corruption affects fertility and savings decisions through the productivity of physical capital.

\subsection{Individual Budget Constraints}

Since individuals do not generate utility from consumption in their first period of life, their income is divided between the cost of raising $x_{t}$ children and saving for future consumption. As an adult, a member of generation $t$ faces the following budget condition:

$$
s_{t}=\left(1-\tau_{t}\right) w_{t} h_{t}-x_{t} z_{t}
$$

Where $s_{t}$ accounts for savings per capita in period $t, z_{t}=b\left(\left(1-\tau_{t}\right) w_{t} h_{t}\right)^{2}$ is the per-child spending, and $b \in\left(0,1 /\left(1-\tau_{t}\right) w_{t} h_{t}\right)$. Unlike standard neoclassical growth models in which the fraction of time (income) devoted to child rearing is exogenous, here, the latter-the fraction of a parent's income devoted to child production, including material goods and education-is endogenous to the process of development. ${ }^{4}$ As it will

\footnotetext{
${ }^{3}$ We could have incorporated consumption in period $t$ into the utility function without affecting the qualitative results of this analysis. In fact, if individuals have logarithmic preferences with respect to consumption in the two periods of life, the fraction of output saved in period $t$ to be consumed in period $t+1$ would be constant. Thus, the dynamical equation that governs the evolution of the economy would be altered only by a multiplicative constant. Notice that our formulation is similar to that of Galor and Weil (1996) in that they too assume zero consumption in the first period of life.

${ }^{4}$ In Raut and Srinivasan (1994), and Cinyabuguma (2011) the cost of raising a child varies over time.
} 
become clear, the child-rearing cost, $b\left(1-\tau_{t}\right) w\left(k_{t}\right) h_{t}$, is proportional to the capital labor ratio. Individuals are homogeneous, and each is endowed with one unit of time-labor which is inelastically supplied on the labor market. The cost of raising a child, $z_{t}$, can also be seen as a transfer of goods or value (or a subtraction from the time available for, and in lieu of purchases of market goods from income earned at work) from parents to children.

On reaching old age (period $t+1$ ), as member of generation $t$, an individual consumes his/her savings with any accrued interest; i.e.,

$$
c_{t+1}=R_{t+1} s_{t}
$$

Where $R_{t+1}=1+r_{t+1}-\delta$, and $\delta=1$ for simplicity. By combining (2.3.1 and 2.3.2), we derive a lifetime budget constraint which equates the value of all resources to the value of all expenditures. This budget is expressed as

$$
R_{t+1} z_{t} x_{t}+c_{t+1}=R_{t+1}\left(1-\tau_{t}\right) w_{t} h_{t}
$$

The right-hand side of (2.3.3) is the potential income available for old-age consumption if the individual were to save all his/her firstperiod income. The left-hand side is the opportunity cost of raising $x_{t}$ children plus all spending on-old age consumption.

\subsection{Individuals' Optimization}

Each parent chooses his fertility $x_{t}$, which implies his consumption $c_{t+1}$ in old-age, anticipating that there is a corruption tax on capital productivity. A parents' optimization problem can be articulated as

$$
\operatorname{Max} U=\ln x_{t}+\beta \ln c_{t+1}
$$

Subject to

$$
\left\{\begin{array}{l}
s_{t}=\left(1-\tau_{t}\right) w_{t} h_{t}\left[1-b\left(1-\tau_{t}\right) w_{t} h_{t} x_{t}\right] \\
c_{t+1}=R_{t+1} s_{t} \\
\left(s_{t}>0, x_{t}>0, c_{t+1}>0\right.
\end{array}\right.
$$

Where, as noted above, $b\left(1-\tau_{t}\right) w_{t} h_{t}$ is the time cost of raising a child. As in Galor and Weil's (1996) setting, the only decision a parent makes at time $t$ in this model is to choose how many children $x_{t}$ to have. The individual's optimization problem is then regarded as a $x_{t}$ that maximizes

$$
\ln x_{t}+\beta \ln \left[R_{t+1}\left(1-\tau_{t}\right) w_{t} h_{t}\left(1-b\left(1-\tau_{t}\right) w_{t} h_{t} x_{t}\right)\right]
$$


The first-order condition for an interior solution amounts to:

$$
c_{t+1}=R_{t+1} \beta b\left(\left(1-\tau_{t}\right) w_{t} h_{t}\right)^{2} x_{t}
$$

This yields an equilibrium condition that equates the marginal utility of having an additional child to the opportunity lost from such a decision. Equation (2.4.3) indicates that increases in the opportunity cost of raising children could motivate parents to substitute more of their resources toward savings. However, if corruption rises, the above opportunity cost falls-by a substitution effect, a parent will want to raise more children relative to savings. On solving (2.4.2), and combining (2.4.3) and (2.3.3), we derive the following demand functions for fertility and savings:

$$
x_{t}=\frac{1}{(1+\beta)\left(1-\tau_{t}\right) w_{t} h_{t}}
$$

and

$$
s_{t}=\frac{\beta}{(1+\beta)}\left(1-\tau_{t}\right) w_{t} h_{t}
$$

It is important to note that corruption matters for decisions about both savings and fertility; it affects (i) an individual's choices through price distortions, and (ii) investment through increased uncertainty and reduced productivity. If the level of corruption is high, the productivity of capital will be low and parents will choose high fertility. Likewise, the savings function depends on corruption through the productivity of capital. If the level of corruption is high, people will save less and, ultimately, the level of output will be low.

\subsection{The Government Problem}

The government receives tax revenue, $\tau_{t} w_{t} h_{t} L_{t}$. A fraction $\left(1-\pi_{t}\right) \epsilon(0,1)$ evaporates through corruption, and only a fraction $\pi_{t}$ is spent on policies and institutions, i.e., property rights and enforcement of contracts, to support production and enhance growth. Therefore, the amount of resources available for productive activities in the next period will be reduced by corruption, and will equal

$$
G_{t+1}=\pi_{t+1} \tau_{t} w_{t} h_{t} L_{t}
$$




\subsection{The Technology}

The basic framework we use in this study is a variant of the Barro (1990) and Barro and Sala-i-Martin (1992) models, which we modify to account for corruption. Following empirical evidence from Silva et al. (2000), we assume that corruption reduces the amount of resources available for proactive policies and institutions, and, hence, reduces the productivity of capital. 5

A single final good is produced by two factors of production: (i) human capital, supplied by young adults, and (ii) physical capital, supplied by older adults. The productivity of physical capital depends on the amount of resources available in the economy for public spending $G_{t}$. The final good produced in period $t$ may be (i) consumed in period $t$, (ii) invested in the production of physical capital that becomes available in period $t+1$, or (iii) utilized to promote proactive policies and productive institutions. The economy at date $t$ consists of $L_{t-1}$ elderly persons and $L_{t}$ young adults. Since all people are alike, there are $L_{t}=x_{t-1} L_{t-1}$ units of labor or working adults at each date $t \geq 0$.

The technology of the final good sector satisfies standard neoclassical properties. So we define the total production function as

$$
Y_{t}=F\left(\pi_{t}, K_{t}, H_{t}\right)=\left[G\left(\pi_{t}\right) K_{t}\right]^{\alpha} H_{t}^{1-\alpha}
$$

Where $G\left(\pi_{t}\right)=\pi_{t} \tau_{t-1} w_{t-1} h_{t-1} L_{t-1}$. Using the production function above and the equilibrium wage below, $G\left(\pi_{t}\right)$ can be written as $\pi_{t} \tau_{t-1}(1-$ $\alpha) \bar{Y}$; with $(1-\alpha) \bar{Y} \equiv w_{t-1} h_{t-1} L_{t-1}$. Equation (2.6.1) exhibits constant returns to scale with respect to $K_{t}$ and $L_{t}$. $K_{t}$ denotes the aggregate domestic supply of physical capital owned by elderly agents, $\alpha \in(0,1)$ is the share of income that goes to capital earnings, $H_{t}=e_{t}^{\varphi} L_{t} ; e_{t}$ denotes on-the-job experience or the extent of "learning by doing" human capital transmission, $G_{t}$ represents government spending on productive institutions such as property rights and the enforcement of contracts, and $\pi_{t}>0$ is the index for absence of corruption; implying that less corruption boosts the productivity of physical capital. ${ }^{6}$

\footnotetext{
${ }^{5}$ As noted earlier, corruption modifies the productivity of physical capital. For instance, two economies with the same amounts of all productive factors and government spending, but with different levels of corruption, will end up with different volumes of production. Less corrupt countries will have greater production, since their capital is more productive. Countries with higher corruption will be less productive.

${ }^{6}$ Silva et al. (2000) estimate the value of $\alpha$ in a Cobb-Douglas technology function and suggested that corruption is a phenomenon that affects economic development only through the productivity of capital.
} 
Let

$$
y_{t}=f\left(G\left(\pi_{t}\right), k_{t}\right)
$$

Where, $k_{t} \equiv \frac{K_{t}}{H_{t}}, y_{t} \equiv \frac{Y_{t}}{H_{t}}$, and $f\left(G(\pi), k_{t}\right)$ is $C^{2}$ and satisfies

$$
\frac{\partial f\left(G\left(\pi_{t}\right), k_{t}\right)}{\partial k_{t}}>0>\frac{\partial^{2} f\left(G\left(\pi_{t}\right), k_{t}\right)}{\partial k_{t}^{2}}, \text { and } f(0)=0
$$

As noted earlier, $\pi_{t}$ corresponds to absence of corruption. Consequently, we should expect a positive relationship between $\pi_{t}$ and $y_{t}$, i.e., $\frac{\partial f\left(G\left(\pi_{t}\right), k_{t}\right)}{\partial \pi_{t}}>0>\frac{\partial^{2} f\left(G\left(\pi_{t}\right), k_{t}\right)}{\partial \pi_{t}^{2}}$

We write the intensive production function as

$$
y_{t}=\mathrm{P}\left(\pi_{t} k_{t}\right)^{\alpha}, \text { where } \mathrm{P} \equiv\left(\tau_{t-1}(1-\alpha) \bar{Y}\right)^{\alpha}
$$

The factor markets in this model are competitive, and the factor rewards for physical capital and labor (all equal to their marginal products) are paid in terms of the final good. Given the structure of the production technology, the factors' marginal products are

$$
\begin{aligned}
& R_{t}=\frac{\partial f\left(\pi_{t}, k_{t}\right)}{\partial k_{t}}=\alpha P \pi_{t}^{\alpha} k_{t}^{\alpha-1} \\
& w_{t}=f\left(\pi_{t}, k_{t}\right)-\frac{k_{t} \partial\left(\pi_{t}, k_{t}\right)}{\partial k_{t}}=(1-\alpha) P \pi_{t}^{\alpha} k_{t}^{\alpha} \equiv w\left(\pi_{t}, k_{t}\right)
\end{aligned}
$$

So far, we have evaluated the impact of corruption on individual choices through the marginal productivity of capital. Following (2.6.4) and (2.6.5), the demand functions given by (2.4.4) and (2.4.5) are also affected by corruption through factor prices, and become

$$
x_{t}=\frac{1}{(1+\beta) b(1-\alpha)\left(1-\tau_{t}\right) P \pi_{t}^{\alpha} k_{t}^{\alpha} h_{t}}
$$

and

$$
s_{t}=\left(\frac{\beta}{(1+\beta)}\right)(1-\alpha)\left(1-\tau_{t}\right) P \pi_{t}^{\alpha} k_{t}^{\alpha} h_{t}
$$

Clearly, $\frac{\partial x_{t}}{\partial \pi_{t}}<0 ; \frac{\partial s_{t}}{\partial \pi_{t}}>0$. A country with less corruption will have a lower fertility rate and more savings than a country with a high level of corruption. Notice that in (2.6.6), fertility depends negatively on the time- 
dependent capital stock, $k_{t}$. The negative relationship between fertility and physical capital is instrumental to the onset of demographic transition during sustained economic development.

\subsection{Accumulation of Factors of Production}

Following (2.6.7), the stock of capital at time $t+1$ is determined by the aggregate supply of savings at time $t$ :

$$
K_{t+1}=L_{t} s_{t}
$$

The equation of motion for working people at time $t+1$ is represented by

$$
H_{t+1}=h_{t+1} L_{t+1}=e_{t+1}^{\varphi} L_{t} x_{t}
$$

Where $e_{t+1}$ is the level of knowledge acquired through learning by doing or experience. The accumulation of knowledge is proportional to the level of the parent's human capital, $h_{t}$, and the number of children, $x_{t}$, as below: ${ }^{7}$

$$
e_{t+1}=\left(\frac{\omega h_{t}}{x_{t}^{\mu}}\right)^{1 / \varphi}
$$

Where $\frac{\partial e_{t+1}}{\partial \pi_{t}}>0, \frac{\partial e_{t+1}}{\partial x_{t}}<0$

This structure allows for the intergenerational transmission of human capital through workplace skills' transmission; no mention is made of the process linking formal education to human capital. ${ }^{8}$

Following Feng et al. (2000), $\omega$ is the maximum rate of intergenerational human capital transmission, and $\mu$ is the dilution effect that results from multiple siblings who are competing for their parents' time. In some traditional or poor countries, it is common for families to share child-rearing costs among parents, aunts, grandparents, and other family members, in which case, parents feel the intensity of child

\footnotetext{
${ }^{7}$ We ignore any issues of child quality in this analysis, focusing only on the quantity of children. Notice that adding another trade-off through the quality of children will only increase the speed of the demographic transition without altering the main conclusion of the model.

${ }^{8}$ Details on the technology of human capital can be found in Feng et al. (2000). Hanushek (1992) and Downey (1995) indicate that an adult's income and ability to transmit human capital to his or her children is inversely related to the number of children.
} 
competition less. However, in rich countries where such practices are almost nonexistent, the competition for parenting time is severely felt by parents and makes having children even more expensive. Consequently, $\mu$ will be high in developed countries and low in developing countries.

We consider that in developing countries $\mu \in\left(0, \frac{1-2 \alpha}{\alpha}\right)$ and that in developed countries $\mu>\frac{1-2 \alpha}{\alpha}$. We will individually cover the case where $\mu=\frac{1-2 \alpha}{\alpha}$. Thus when family size is small, parents will provide more nurturing per child and the adult productivity will be enhanced. Globally speaking, we capture the structure of the human capital of each child $h_{t+1}$ by relating parental human capital $h_{t}$ and the number of children in the household $x_{t}$ as follows:

$$
h_{t+1}=\left(\frac{\omega h_{t}}{x_{t}^{\mu}}\right)
$$

As follows from (2.6.6) and (2.7.1), physical capital per effective unit of labor can now be defined as

$$
k_{t+1}=\left(\frac{s_{t}}{e_{t+1}^{\varphi} x_{t}}\right)
$$

Where from (2.6.6) and (2.6.7), (2.7.3) becomes

$$
k_{t+1}=\left(\frac{\beta b\left((1-\alpha)\left(1-\tau_{t}\right) P \pi_{t}^{\alpha}\right)^{2} k_{t}^{2 \alpha} h_{t}^{2}}{e_{t+1}^{\varphi}}\right)
$$

Since $e_{t+1}^{\varphi}=\frac{\omega h_{t}}{\left[(1+\beta) b(1-\alpha)\left(1-\tau_{t}\right) P \pi_{t}^{\alpha} k_{t}^{\alpha} h_{t}\right]^{\mu}}$ we have to rewrite (2.7.4) as:

$$
k_{t+1}=\Omega_{t} k_{t}^{\alpha(2+\mu)} \equiv \phi\left(k_{t}\right)
$$

with $\Omega_{t}=\left(\frac{\beta}{\omega}\right)(1+\beta)^{\mu}\left(b h_{t}\right)^{1+\mu}\left((1-\alpha)\left(1-\tau_{t}\right) P \pi_{t}^{\alpha}\right)^{2+\mu}$

$$
\phi^{\prime}\left(k_{t}\right)>0, \forall \mu>0, \text { and } \mathrm{P}=\left(\tau_{t-1}(1-\alpha) \bar{Y}\right)^{\alpha} \quad 9
$$

\footnotetext{
${ }^{9}$ An increase in parent's human capital or a decrease in corruption helps the accumulation of physical capital of the next generation.
} 


\subsubsection{Dynamic Equilibrium}

The dynamic system is governed by the evolution of per-unit-ofeffective labor physical capital from a historical given initial stock $k_{0}$. Instances in which 0 is the only feasible capital stock may occur in this model when the slope of $\phi\left(k_{t}\right)$ is less than one, that is: $\phi^{\prime}\left(k_{t}\right)<1$. Assuming the long-run, and $\forall k>0$, this equation yields the following condition: 10

$$
\pi \leq\left(\frac{\omega k^{1-\alpha(2+\mu)}}{\alpha(2+\mu) \beta(1+\beta)^{\mu}(b h)^{1+\mu}\left((1-\alpha)\left(1-\tau_{t}\right)\left(\tau_{t-1}(1-\alpha) \bar{Y}\right)^{\alpha}\right)^{2+\mu}}\right)^{\frac{1}{\alpha(2+\mu)}} \equiv \bar{\pi}
$$

Thus, $\bar{\pi}$ is the threshold level of absence of corruption below which 0 is the only feasible steady state for capital stock. With a logarithmic utility function, a Cobb-Douglas production function, endogenous fertility, and a positive dilution, $\mu$, any study of the steady state should discuss the concavity of $\phi$ :

$$
\Phi^{\prime \prime}\left(k_{t}\right)=\alpha(2+\mu)(\alpha(2+\mu)-1) \Omega_{t} k_{t}^{\alpha(2+\mu)-2}
$$

When $\mu \in\left(0, \frac{1-2 \alpha}{\alpha}\right)$ and $\pi>\bar{\pi}$, we have $\phi^{\prime \prime}\left(k_{t}\right)<0$ and $\phi\left(k_{t}\right)$ is strictly concave. Moreover $\phi(0)=0$, and 0 becomes an unstable corner solution. However, when $\pi \leq \bar{\pi}, 0$ is a globally stable corner solution. In each case where $\pi>\bar{\pi}$, and for any $k_{0}>0$, there exists a unique, globally stable state given by:

$$
\left.k_{t}^{*}=\left(\frac{\beta(1+\beta)^{\mu}\left(b h_{t}\right)^{1+\mu}}{\omega\left(\pi_{t}^{\alpha}(1-\alpha)\left(1-\tau_{t}\right)\left(\tau_{t-1}(1-\alpha) \bar{Y}\right)^{\alpha}\right.}\right)^{-(2+\mu)}\right)^{\frac{1}{1-\alpha(2+\mu)}}
$$

Assuming that condition 2.7.6 does not hold, the function $\phi\left(k, \pi_{1}\right)$ in Figure 1 depicts the path of an economy beset by severe corruption. In the same Figure 1 , when $\pi>\bar{\pi}, \phi\left(k, \pi_{2}\right)$ and $\phi\left(k, \pi_{3}\right)$ represent paths for moderate and low corruption, respectively.

\footnotetext{
${ }^{10}$ For simplicity's sake, I will drop the time subscript on $\pi$ whenever writing condition (2.7.6).
} 
Figure 1: A time path of an economy with $\mu \in\left(0, \frac{1-2 \alpha}{\alpha}\right)$

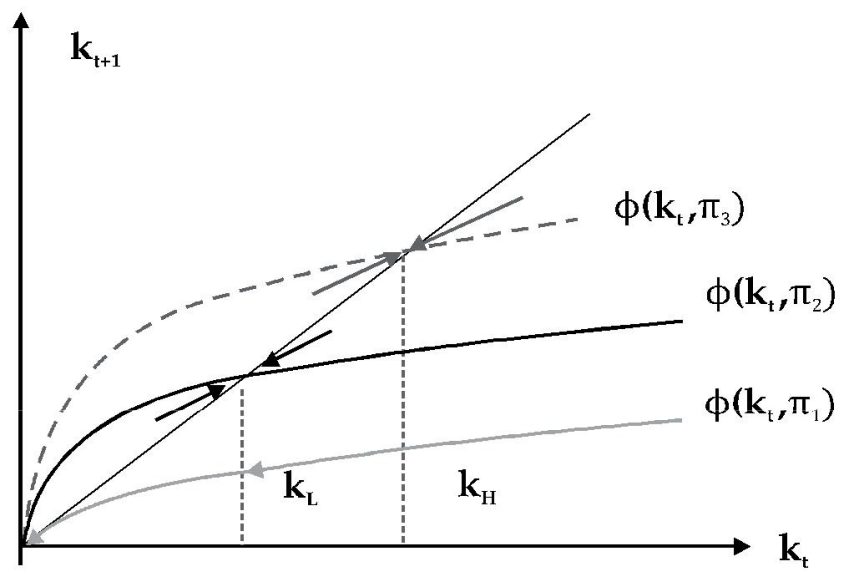

When $\mu=\frac{1-2 \alpha}{\alpha}$, and $\pi>\bar{\pi}$, we have an AK model, i.e., $\phi\left(k_{t}\right)$ is a linear function, and $\phi^{\prime \prime}\left(k_{t}\right)=0$. When $\pi \leq \bar{\pi}, \phi(0)=0$ is the only steady state (0 is a globally stable steady state). Figure 2 below depicts three different paths, $\phi\left(k, \pi_{1}\right), \phi\left(k, \pi_{2}\right)$, and $\phi\left(k, \pi_{3}\right)$, corresponding to three different levels of corruption, namely: $\pi_{1}<\pi_{2}<\pi_{3}$.

Figure 2: A time path of an economy with $\mu=\frac{1-2 \alpha}{\alpha}$

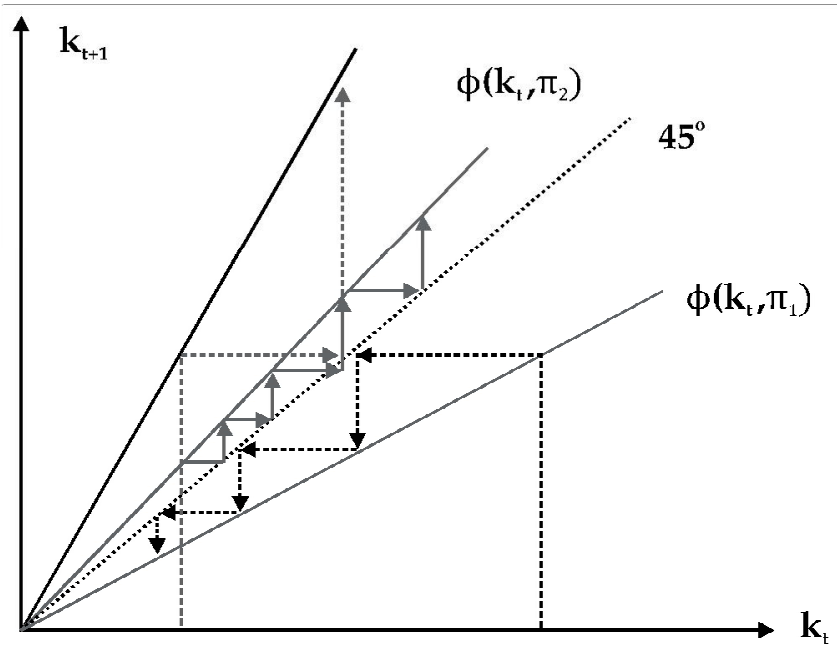

When $\mu>\frac{1-2 \alpha}{\alpha}$, and $\pi>\bar{\pi}$, we have $\phi^{\prime \prime}\left(k_{t}\right)>0$ and $\phi\left(k_{t}\right)$ is strictly convex. Moreover $\phi(0)=0$, and 0 is a locally unstable corner solution. 0 becomes a globally stable solution when $\pi \leq \bar{\pi}$. In addition, for each level of $\pi: \pi>\bar{\pi}$, there is an unstable non zero steady state given by 


$$
\left.k_{t}^{*}=\left(\frac{\omega\left(\pi_{t}^{\alpha}(1-\alpha)\left(1-\tau_{t}\right)\left(\tau_{t-1}(1-\alpha) \bar{Y}\right)^{\alpha}\right.}{\beta(1-\beta)^{\mu}\left(b h_{t}\right)^{1+\mu}}\right)^{-(2+\mu)}\right)^{\frac{1}{\alpha(2+\mu)-1}}
$$

In the " $\phi\left(k, \pi_{3}\right) "$ case, where $\pi \geq \bar{\pi}_{3}$, the zero steady state is not possible provided that the initial capital stock sufficiently high, i.e., $k_{0}>0$; (See Figure 3 below). Therefore, at higher levels of $\pi, \pi \geq \bar{\pi}_{3}$, the economy is no longer trapped in low-growth, low-investment equilibrium. Instead, it enters the modern growth regime under which income per capita rises and fertility declines. This feature of the model is consistent with historical evidence associated with most industrialized countries, such as the UK, France, Sweden, and Germany (McEvedy and Jones, 1978).

Figure 3: A time path of an economy with $\mu>\frac{1-2 \alpha}{\alpha}$

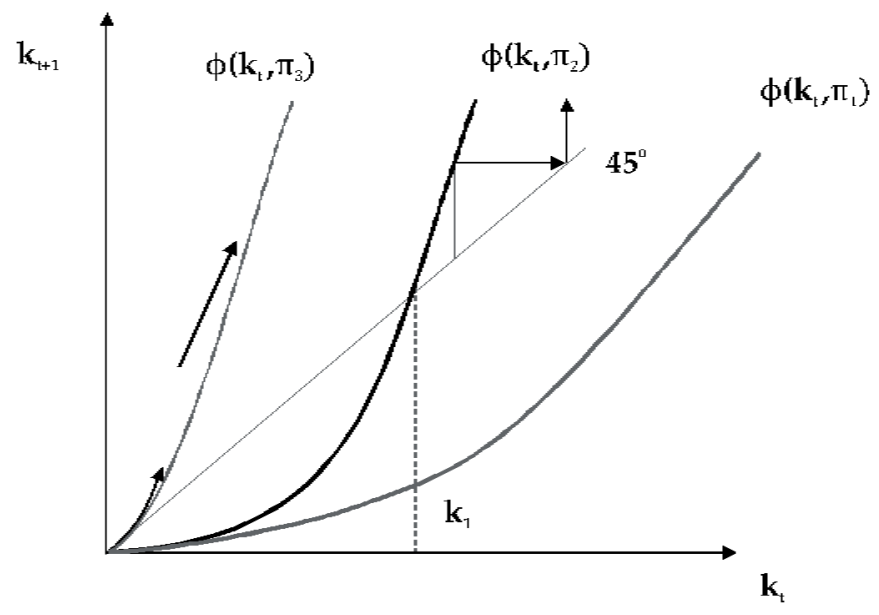

\section{To summarize:}

Lemma 1: Given the production function in (2.6.1) and assuming that $\pi>\bar{\pi}$, an increase in $\pi_{t}$ has the following effects:

The steady state level of $k_{t}$ increases when $\mu \in\left(0, \frac{1-2 \alpha}{\alpha}\right)$

The steady state level of $k_{t}$ decreases when $\mu>\frac{1-2 \alpha}{\alpha}$

Proof: The proof of lemma 1 follows from equations (2.7.8) and (2.7.9) by taking their derivatives with respect to $\pi_{t}$.

When $\mu>\frac{1-2 \alpha}{\alpha}$ we obtain an unstable steady state that yields the threshold level of physical capital above which rich economies would 
enter a modern growth regime. A fall in this threshold suggests that, in rich countries, less corruption reduces the risk of falling into-low level equilibrium. Consequently, changes in $\pi_{t}$ affect steady states levels of $y_{t}$.

Proposition 2: Given the results of Lemma 1 and assuming that $\pi>\bar{\pi}$, an increase in $\pi_{t}$ affects the growth rate of output per effective labor.

Proof: In the steady-state, the growth rate of output per effective unit of $\gamma_{\mathrm{y}}$, depends solely on $\pi_{\mathrm{t}}$. Letting $\mathrm{y}_{\mathrm{t}}$ be the level of output per effective labor and $\mathrm{y}_{\mathrm{t}}=\mathrm{P} \pi_{\mathrm{t}}^{\alpha} \mathrm{k}_{\mathrm{t}}^{\alpha}$; and assuming the steady state, we obtain

$$
\gamma_{y}=\left(\frac{d P / d t}{P}\right)+\alpha\left(\frac{d \pi_{t} / d t}{\pi_{t}}\right)+\alpha\left(\frac{d k_{t} / d t}{k_{t}}\right)=\alpha \sigma
$$

Where

$$
\sigma=\frac{d \pi_{t} / d_{t}}{\pi_{t}}, \text { and } \frac{d k_{t} / d t}{k_{t}}=\frac{d P / d t}{P}=0
$$

This proposition implies that, in the long run, even when the stock of capital per effective unit of labor does not change, output per effective unit of labor grows or shrinks at the rate of change in the level of corruption. In fact, an economy with less corruption will grow faster because it will attract more investment, induce lower fertility, allow for greater human capital transmission, and permit a high level of physical capital accumulation.

\subsubsection{Fertility and Development Trajectory}

In the steady state, and as noted above from (2.4.4), (2.6.6) and (2.7.8) or (2.7.9), $k_{t}^{*}$ determines uniquely a stationary fertility rate:

$$
x\left(k_{t}^{*}\right)=\frac{1}{(1+\beta) b(1-\alpha)\left(1-\tau_{t}\right) P \pi_{t}^{\alpha} k_{t}^{* \alpha} h_{t}}, \mathrm{P} \equiv\left(\tau_{t-1}(1-\alpha) \bar{Y}\right)^{\alpha}
$$

The demographic transition can be linked to reductions in corruption through capital productivity. Along the development path and during the transition to balanced growth, fertility depends on $k_{t}$; and as corruption decreases, existing capital becomes more productive, the opportunity cost of raising children increases, and fertility declines. Following (2.4.4), (2.6.5), and (2.7.5), and taking the derivative of (2.6.6) with respect to $k_{t}$, we obtain that: 


$$
\frac{\partial x_{t}}{\partial k_{t}}=\left(\frac{-\alpha}{(1+\beta) b(1-\alpha)\left(1-\tau_{t}\right) P \pi_{t}^{\alpha} k_{t}^{\alpha} h_{t} k_{t}}\right)<0
$$

The above equation indicates that during the transition to balanced growth, fertility depends negatively on both $\pi_{t}$ and $k_{t}$. Thus, this model does capture the demographic transition.

\section{To summarize:}

Proposition 3: During the transition from low-level equilibrium to sustained economic growth, reductions in corruption followed by increases in marginal productivity of capital are instrumental to the onset of demographic transition.

Proof: The proof of this result follows from equation (2.7.10) and Lemma 1.

\section{Empirical Analysis}

In our model, long-run growth and demographic transition are viewed as outcomes of decreases in corruption, followed by increases in capital productivity. This phenomenon is reinforced by incorporating endogenous child-rearing costs in the model. Understanding how fertility responds to changes in corruption becomes crucial to the study of longrun growth and the demographic transition. Therefore, our empirical strategy emphasizes the model's implications for fertility.

As noted above and following (2.6.6), this model predicts that (i) fertility falls when corruption decreases, (ii) the amount of physical capital grows, and (iii) parents' level of education increases. Our regression model is derived from (2.6.6) by applying the log transformation on both sides of the equation as

$$
\ln x_{t}=\ln \left(\frac{1}{(1+\beta) b(1-\alpha)\left(1-\tau_{t}\right) P \pi_{t}^{\alpha} k_{t}^{\alpha} h_{t}}\right)
$$

or equivalently,

$$
\ln x_{i t}=\alpha_{0}+\alpha_{1} \ln \pi_{i t}+\alpha_{2} \ln k_{i t}+\varphi \ln e_{i t}+u_{i t}
$$

Where $\alpha_{0} \equiv \ln \left((1+\beta) b(1-\alpha)\left(1-\tau_{t}\right) P\right)$, and $h_{t}=e_{t}^{\varphi} \quad 11$

\footnotetext{
${ }^{11}$ In this particular regression equation where fertility is the endogenous variable, $\alpha_{1}$ and $\alpha_{2}$ do not need to be equal.
} 
We use fixed effects models to properly address any unobserved heterogeneity that might be correlated with our independent variables:

$$
\ln x_{i t}=\alpha_{0}+\alpha_{1} \ln \pi_{i t}+\alpha_{2} \ln k_{i t}+\varphi \ln e_{i t}+Z_{i}+\eta_{i}+u_{i t}
$$

Where $\ln x_{i t}$ is the $\log$ of total fertility rate observed for country $i$ at time $t, \ln \pi_{i t}$ is the $\log$ of absence of corruption, $\ln k_{i t}$ is the log of physical capital per effective labor, $\ln e_{i t}$ is the $\log$ of completed secondary education, $Z_{i}$ is a vector of time invariant-variables, $\eta_{i}$ is the unobserved country effect, $X_{i t}$ is the time variant regressor, and $u_{i t}$ is the error term. $\eta_{i}$ is associated with sociocultural and historical factors. We assume that $\eta_{i}$ is not independent of $X_{i t}, Z_{i} \cdot{ }^{12}$

To get rid of country effects $\eta_{i}$, a within transformation is applied to the data, and $\alpha_{1}, \alpha_{2}$, and $\varphi$ are then estimated using ordinary least squares.

Our data covers the period 1960-2000 for about 94 countries. We organize all data on fertility rates and other variables for which measures are available into eight half-decade observation periods for 1965-69, 197074 , etc., to account for any missing observations for some sub-periods. This gives us between five and eight observations for most countries.

Data and sources used are: Gross Domestic Product per capita (GDPpc), Total Fertility Rate, the percentage of the population that belongs to the Catholic faith (Catholic), the percentage of the population that belongs to the Muslim faith (Muslim), the percentage of the population that belongs to the Protestant faith (Protestant), Latitude, British Legal Origin (Leg_British), and French Legal Origin (Leg_French) are from the World Bank (WDI, 2010). Data on schooling ((Schooling), Average years of schooling for those 25 years old and over) were from Barro and Lee (2000). Data on corruption is based on the Corruption Perception Index (CPI) from Transparency International, and is available from 1995. We used a five-year average from 1995-2000. (http://www.transparency.org/policy_research/surveys_indices/cpi.)

In Tables 1 and 2, we use the log of the total fertility rate as our dependent variable, and a set of independent variables that includes

\footnotetext{
${ }^{12}$ For simplicity's sake, the empirical model will use log of GDP per capita as a proxy for log of physical capital stock, $k_{i t}$. Because of data limitation on literacy rate, we use completed secondary education to proxy for human capital. In this very particular case, literacy rate would have been the best proxy for human capital acquired through experience and learning by doing. However, both years of education and literacy rate are correlated, and literacy rate is included in the years of education since it measures the proportion of the population that has achieved a given minimum level of education.
} 
measures of education, GDP per capita, corruption, and a number of income dummies. The model also includes a dummy variable for subSaharan countries. We control for religious factors (the proportion of population that is Catholic, Muslim, or Protestant). Religion and countries' legal origins play key roles in explaining heterogeneous fertility trends across countries and over time (Bloom \& Humair, 2010). Following tests to determine endogeneity and over-identification (see Table 2), legal origins are best used as an instrument for corruption. The first-stage results (Table A1 in Appendix 1) suggest that legal origins affect fertility through corruption. Table 1 reports the fixed effects results of a panel data analysis of equation (3.0.1).

Turning to the estimates, the coefficients of $\ln$ (GDPpc) and $\ln$ (Schooling) are always significant and have the expected signs across all regressions. A 1-percent rise in GDPpc leads to a fall of about 0.27 percent in the fertility rate; likewise, a 1-percent rise in the level of an adult parent's human capital in period $t$ causes the fertility rate to fall by about 0.04 percent. Measures of corruption were included in columns 1-4 of Table 1, and appeared statistically significant in all columns but the fourth, even after controlling for various other determinants suggested in this article, such as per-capita income and religious factors.

We included dummy variables for low-, middle-, and high-income countries as well as for sub-Saharan countries to test that our results were not due to missing-variable bias. ${ }^{13}$ The dummy for low-income countries carried a positive sign but was not statistically significant. Dummies for middle-income and sub-Saharan countries were all statistically significant $(p<0.05)$ with positive signs, suggesting that fertility is likely to be high both in middle-income and sub-Saharan countries.

Of particular interest is the dummy variable for high-income countries in the fourth column. While this variable is statistically significant, it has an unexpected negative sign, and whenever it is accounted for in the model, the coefficient of the corruption variable becomes negative and insignificant. This phenomenon suggests that the dummy variable reflects other variables that might affect fertility in high-income countries.

We used slope dummy variables in which corruption interacted with each of the three dummies for income levels (low, middle, and high).

${ }^{13}$ Using World Bank values, we classify countries as low-, middle-, or high-income. The World Bank's criteria classify countries with per capita income (in 1997 figures) (i) below USD785 as lowincome, (ii) USD785-9,655 as middle-income, and (ii) equal to or above USD9,655 as high-income. 


\section{Table 1: Fixed Effects (within) Regression with Level and Slope Dummies}

Dependent variable $=\log ($ total fertility rate $)$

\begin{tabular}{|c|c|c|c|c|c|c|}
\hline Indep't variable & 1 & 2 & 3 & 4 & 5 & 6 \\
\hline InGDPpca & $\begin{array}{l}-0.293^{* * *} \\
(0.019)\end{array}$ & $\begin{array}{l}-0.289 * * * \\
(0.019)\end{array}$ & $\begin{array}{l}-0.287^{* * * *} \\
(0.019)\end{array}$ & $\begin{array}{l}-0.213^{* * * *} \\
(0.019)\end{array}$ & $\begin{array}{l}-0.281 \text { *** } \\
(0.019)\end{array}$ & $\begin{array}{l}-0.251 * * * \\
(0.016)\end{array}$ \\
\hline InSchooling ${ }^{\mathrm{b}}$ & $\begin{array}{l}-0.039^{* * *} \\
(0.012)\end{array}$ & $\begin{array}{l}-0.037^{* * *} \\
(0.013)\end{array}$ & $\begin{array}{l}-0.059^{* * *} \\
(0.013)\end{array}$ & $\begin{array}{l}-0.043^{* * *} \\
(0.011)\end{array}$ & $\begin{array}{l}-0.023^{* * *} \\
(0.013)\end{array}$ & $\begin{array}{l}-0.039^{* * *} \\
(0.012)\end{array}$ \\
\hline InCorruptionc & $\begin{array}{l}0.095^{* * *} \\
(0.022)\end{array}$ & $\begin{array}{l}0.097^{* * *} \\
(0.023)\end{array}$ & $\begin{array}{l}0.040^{*} \\
(0.024)\end{array}$ & $\begin{array}{l}-0.0006 \\
(0.022)\end{array}$ & $\begin{array}{l}0.101^{* * *} \\
(0.022)\end{array}$ & \\
\hline Catholica & $\begin{array}{l}0.0032^{* * *} \\
(0.0003)\end{array}$ & $\begin{array}{l}0.0032^{* * *} \\
(0.0004)\end{array}$ & $\begin{array}{l}0.0028^{* * *} \\
(0.0004)\end{array}$ & $\begin{array}{l}0.0021 * * * \\
(0.0003)\end{array}$ & $\begin{array}{l}0.0033^{* * *} \\
(0.0003)\end{array}$ & $\begin{array}{l}0.0023^{* * *} \\
(0.0003)\end{array}$ \\
\hline Muslima & $\begin{array}{l}0.0046^{* * *} \\
(0.0004)\end{array}$ & $\begin{array}{l}0.0046^{* * *} \\
(0.0004)\end{array}$ & $\begin{array}{l}0.0041^{* * *} \\
(0.0004)\end{array}$ & $\begin{array}{l}0.0034^{* * *} \\
(0.0004)\end{array}$ & $\begin{array}{l}0.0047^{* * *} \\
(0.0004)\end{array}$ & $\begin{array}{l}0.0033^{* * *} \\
(0.0004)\end{array}$ \\
\hline Protestant ${ }^{a}$ & $\begin{array}{l}0.0043^{* * *} \\
(0.0006)\end{array}$ & $\begin{array}{l}0.0043^{* * *} \\
(0.0006)\end{array}$ & $\begin{array}{l}0.0036^{* * *} \\
(0.0006)\end{array}$ & $\begin{array}{l}0.003^{* * *} \\
(0.0006)\end{array}$ & $\begin{array}{l}0.004^{* * *} \\
(0.0006)\end{array}$ & $\begin{array}{l}0.002^{* * *} \\
(0.0005)\end{array}$ \\
\hline DLowInc & & $\begin{array}{l}0.0166 \\
(0.0351)\end{array}$ & & & & \\
\hline DMdlInc & & & $\begin{array}{l}0.125^{* * *} \\
(0.023)\end{array}$ & & & \\
\hline DHighInc & & & & $\begin{array}{l}-0.358^{* * *} \\
(0.036)\end{array}$ & & \\
\hline SSA & & & & & $\begin{array}{l}0.087^{* * *} \\
(0.032)\end{array}$ & \\
\hline CorXLowIncc & & & & & & $\begin{array}{l}0.026^{* * *} \\
(0.006)\end{array}$ \\
\hline CorXMdlIncc & & & & & & $\begin{array}{l}0.028^{* * *} \\
(0.005)\end{array}$ \\
\hline CorXHighInc ${ }^{c}$ & & & & & & $\begin{array}{l}-0.033^{* * *} \\
(0.009)\end{array}$ \\
\hline Constant & $\begin{array}{l}3.437^{* * *} \\
(0.1686)\end{array}$ & $\begin{array}{l}3.401 * * * \\
(0.1850)\end{array}$ & $\begin{array}{l}3.474^{* * *} \\
(0.1654)\end{array}$ & $\begin{array}{l}3.119 * * * \\
(0.1610)\end{array}$ & $\begin{array}{l}3.282^{* * *} \\
(0.1770)\end{array}$ & $\begin{array}{l}3.223^{* * *} \\
(0.1370)\end{array}$ \\
\hline $\begin{array}{l}\text { No. of } \\
\text { observations }\end{array}$ & 689 & 689 & 689 & 689 & 689 & 713 \\
\hline R overall & 0.72 & 0.72 & 0.74 & 0.74 & 0.72 & 0.74 \\
\hline$F(k, \mathrm{n})$ & 308.16 & 263 & 278 & 314 & 267.6 & 184.4 \\
\hline P-value & $(0.000)$ & $(0.000)$ & $(0.000)$ & $(0.000)$ & $(0.000)$ & $(0.000)$ \\
\hline
\end{tabular}

Notes: The table presents fixed effect estimates of model's coefficients via within (between) regression model. Standard errors are given in parentheses. Asterisks $*^{*}{ }^{* *}$, and ${ }^{* * *}$ indicate significance at 10,5 , and 1 percent levels, respectively.

Sources: Data used to calculate variables is from: $\mathrm{a}=$ the World Bank (2010); $\mathrm{b}=$ Barro and Lee (2000) for average number of years of schooling for those aged 25 or over; $\mathrm{c}=$ corruption perception index from Transparency International (available from 1995; we used a five-year average for the period 1995-2000). 
The results presented in column 5 of Table 1 indicate that fertility increases with corruption in low- and middle-income countries, and decreases when corruption rises in high-income countries. This last result might relate to the fact that high-income countries' fertility rates have dropped below the replacement level. We were concerned by a possible endogeneity bias between fertility and corruption. A reverse causality between fertility and corruption may run through income inequality. In fact, high fertility rates foster income inequality within and across countries, and income inequality, in turn, increases corruption (You \& Khagram, 2005).

Table 2 reports the estimates of a set of two-stage least-squares (2SLS) regression models in which latitude and legal origins are used as instruments to predict corruption, assuring that all our results pass the tests for endogeneity of the latter variables and for over-identifying restrictions. ${ }^{14}$

There are good reasons to expect legal origin and latitude to perform well as instruments for corruption in a regression involving fertility. There is a strong affinity between a country's legal origins and the historical presence of a colonizing power. Consistent with this, corruption was much higher in countries with French legal origins than in those with British legal origins (in fact, countries tend to inherit their colonizers' institutions). 15 Likewise, latitude was found significantly related to productivity growth, which, in turn, is shaped by the quality of existing institutions, including the level of corruption. For example, Mauro (1995), La Porta, Lopez-de-Silanes, Shleifer, and Vishny (1998), and Hall and Jones (1999), among others, have suggested that distance from the equator (latitude) can be used as an instrument for corruption in income-inequality regressions.

\footnotetext{
${ }^{14}$ We use the Wu-Hausman and Durban-Wu-Hausman tests of endogeneity to assess that the instruments successfully predict the relevant endogenous variable. We use the Sargan and Basmann tests of overidentifying restrictions to ensure that the instruments can be excluded from the 2SLS regression.

${ }^{15}$ Fredriksson and Svensson (2002) use the legal origins of a country as an instrument for corruption: They claim that the legal system of the country affects the way property rights are set and this, in turn, affects corruption.
} 
Table 2: 2SLS Regressions for IV Models

Dependent variable $=\log ($ Total Fertility rate $)$

\begin{tabular}{|c|c|c|c|c|c|}
\hline Indep't variable & 1 & 2 & 3 & 4 & 5 \\
\hline InGDPpc $^{a}$ & $\begin{array}{l}-0.148^{* * *} \\
(0.033)\end{array}$ & $\begin{array}{l}-0.148^{* * *} \\
(0.037)\end{array}$ & $\begin{array}{l}-0.147^{* * *} \\
(0.038)\end{array}$ & $\begin{array}{l}-0.149^{* * *} \\
(0.032)\end{array}$ & $\begin{array}{l}-0.148^{* * *} \\
(0.034)\end{array}$ \\
\hline InSchoolingb & $\begin{array}{l}-0.078^{* * *} \\
(0.014)\end{array}$ & $\begin{array}{l}-0.078^{* * *} \\
(0.015)\end{array}$ & $\begin{array}{l}-0.076^{* * *} \\
(0.016)\end{array}$ & $\begin{array}{l}-0.077^{* * *} \\
(0.015)\end{array}$ & $\begin{array}{l}-0.078^{* * *} \\
(0.015)\end{array}$ \\
\hline InCorruptionc & $\begin{array}{l}0.374^{* * *} \\
(0.058)\end{array}$ & $\begin{array}{l}0.372^{* * *} \\
(0.062)\end{array}$ & $\begin{array}{l}0.378^{* * *} \\
(0.087)\end{array}$ & $\begin{array}{l}0.393^{* * *} \\
(0.102)\end{array}$ & $\begin{array}{l}0.375^{* * *} \\
(0.058)\end{array}$ \\
\hline Catholica & $\begin{array}{l}0.0023^{* * *} \\
(0.0004)\end{array}$ & $\begin{array}{l}0.0023^{* * *} \\
(0.0004)\end{array}$ & $\begin{array}{l}0.0024^{* * *} \\
(0.0004)\end{array}$ & $\begin{array}{l}0.0025^{* * *} \\
(0.0005)\end{array}$ & $\begin{array}{l}0.0023^{* * *} \\
(0.0005)\end{array}$ \\
\hline Muslima & $\begin{array}{l}0.0041^{* * *} \\
(0.0005)\end{array}$ & $\begin{array}{l}0.0041^{* * *} \\
(0.0005)\end{array}$ & $\begin{array}{l}0.0041^{* * *} \\
(0.0005)\end{array}$ & $\begin{array}{l}0.0042^{* * *} \\
(0.0006)\end{array}$ & $\begin{array}{l}0.0041^{* * *} \\
(0.0005)\end{array}$ \\
\hline Protestanta & $\begin{array}{l}0.0083^{* * *} \\
(0.001)\end{array}$ & $\begin{array}{l}0.0083^{* * *} \\
(0.0001)\end{array}$ & $\begin{array}{l}0.0083^{* * *} \\
(0.0013)\end{array}$ & $\begin{array}{l}0.0086^{* * *} \\
(0.002)\end{array}$ & $\begin{array}{l}0.0083^{* * *} \\
(0.001)\end{array}$ \\
\hline DLowInc & & $\begin{array}{l}-0.002 \\
(0.043)\end{array}$ & & & \\
\hline DMdlInc & & & $\begin{array}{l}0.0077 \\
(0.044)\end{array}$ & & \\
\hline DHighInc & & & & $\begin{array}{l}-0.032^{* * *} \\
(0.087)\end{array}$ & \\
\hline SSA & & & & & $\begin{array}{l}-0.007 \\
(0.038)\end{array}$ \\
\hline Constant & $\begin{array}{l}1.856^{* * * *} \\
(0.347)\end{array}$ & $\begin{array}{l}1.870^{* * *} \\
(0.389)\end{array}$ & $\begin{array}{l}1.853^{* * *} \\
(0.429)\end{array}$ & $\begin{array}{l}1.828^{* * * *} \\
(0.416)\end{array}$ & $\begin{array}{l}1.860^{* * *} \\
(0.355)\end{array}$ \\
\hline $\begin{array}{l}\text { No. of } \\
\text { observations }\end{array}$ & 689 & 689 & 689 & 689 & 689 \\
\hline Adjusted E" & 0.64 & 0.64 & 0.64 & 0.763 & 0.64 \\
\hline Sargan $\left(X^{2}\right)$ & $6.08(0.11)$ & $6.1(0.11)$ & $6.13(0.11)$ & $5.98(0.11)$ & $6.19(0.10)$ \\
\hline Basmann $\left(X^{2}\right)$ & $6.05(0.11)$ & $6.05(0.11)$ & $6.08(0.11)$ & $5.94(0.11)$ & $6.14(0.10)$ \\
\hline WH (X"2) & $57.9(0.00)$ & $53.1(0.00)$ & $34.12(0.00)$ & $29.69(0.00)$ & $58.75(0.00)$ \\
\hline $\mathrm{DWH}(\mathrm{F})$ & $54.0(0.00)$ & $49.9(0.00)$ & $32.92(0.00)$ & $28.82(0.00)$ & $54.79(0.00)$ \\
\hline \multirow[t]{4}{*}{ Instruments ${ }^{a}$} & Latitude & Latitude & Latitude & Latitude & Latitude \\
\hline & Latitude sq. & Latitude sq. & Latitude sq. & Latitude sq. & Latitude sq. \\
\hline & LegalBritish & LegalBritish & LegalBritish & LegalBritish & LegalBritish \\
\hline & LegalFrench & LegalFrench & LegalFrench & LegalFrench & LegalFrench \\
\hline
\end{tabular}

Notes: Over-identifying restrictions are conducted through the Sargan $\left(\chi^{2}\right)$ and Basmann $\left(\chi^{2}\right)$ tests; endogeneity tests are conducted through the Wu-Hausman f-test $(\mathrm{F})$ and Durbin-Wu-Hausman $\left(\chi^{2}\right)$ test. P-values are given in parentheses. Asterisks*, **, and ${ }^{* * *}$ indicate significance at 10,5 , and 1 percent levels, respectively.

Sources: Data used to calculate variables is from: $\mathrm{a}=$ the World Bank (2010); $\mathrm{b}=$ Barro and Lee (2000) for average number of years of schooling for those aged 25 or over; $\mathrm{c}=$ corruption perception index from Transparency International (available from 1995; we used a five-year average for the period 1995-2000). 
Overall, the 2SLS results in Table 2 are far better than the fixed effects results in Table 1 . The coefficients of all corruption variables were much larger and remained statistically significant at 1 percent in all five regressions in which they were included, even after controlling for income per capita, religion-related variables, legal origins, and various dummy variables. Likewise, the coefficients of schooling were much larger and remained significant at 1 percent with the predicted signs. The coefficients of $\ln (\mathrm{GDPpc})$ shrank by about 50 percent but remained statistically significant at 1 percent and carried the expected sign. The dummy for high income was also significant at 1 percent but carried a negative sign, suggesting that fertility decreases in high-income countries. However, unlike the results in column 4 of Table 1, here the coefficient of corruption remained highly statistically significant with the expected sign. Other dummies for low- and middle-income countries were only significant in the first-stage regressions.

The results presented in Tables 1 and 2 support the main prediction of our model, i.e., that decreases in corruption reduce fertility and stimulate economic growth. Our findings provide additional insights into the effects of corruption on fertility in developing versus developed countries. ${ }^{16}$

\section{Conclusion}

In this article, we wanted to show that reduction in corruption is one of the major driving forces behind economic growth and demographic transition. We constructed a simple theoretical model in which corruption (i) modifies the productivity of physical capital by reducing the amount of resources available for proactive policies and productive economic activities, and (ii) affects the opportunity cost of raising children. Unlike standard growth models in which child-rearing costs are exogenous, we endogenized the opportunity cost of raising children to properly account for parents' trade-off between working and raising children. Both our theoretical and empirical results suggest that, during the transition from a low-level equilibrium to sustained economic growth, reductions in corruption, followed by increases in the marginal productivity of capital, are instrumental to the onset of demographic transition. Results based on fixed effects and 2SLS regressions indicate that corruption is highly predictive of fertility, even after controlling for GDP per capita, education, and religious and historical factors, such as legal origins.

\footnotetext{
${ }^{16}$ In all Tables, we were concerned with a possible endogeneity between $y_{t}$ and fertility rate. We tested this by replacing $y_{t}$ with its lags and we find the regression results did not change.
} 
In addition, our results indicate that fertility increases in both middle-income and sub-Saharan African countries, while it decreases in high-income countries. The effect of corruption on fertility remains statistically significant and positive in both low- and middle-income countries, but negative and statistically significant in high-income countries. Further research will extend this model to endogenize corruption and to account for the three regimes of demographic transition: the Malthusian Regime, the Post-Malthusian Regime, and the Modern Growth Regime. 


\section{References}

Aschauer, D. A. (1989). Is public expenditure productive? Journal of Monetary Economics, 23, 177-200.

Barro, R. J. (1990). Government spending in a simple model of endogenous growth. Journal of Political Economy, 98, 103-125.

Barro, R. J., \& Lee, J. (2000). International data on educational attainment: Updates and implications (Working Paper No. 42). Cambridge, MA: Center for International Development, Harvard University.

Barro, R. J., \& Sala-i-Martin, X. (1992). Convergence. Journal of Political Economy, 100, 223-251.

Basso, A., \& Vilalta, D. C. (2011). Institutions, culture and the onset of the demographic transition (Working Paper No. 2011-13). Valencia, Spain: Instituto Valenciano de Investigaciones Económicas.

Becker, G. S., \& Barro, R. J. (1988). A reformulation of the economic theory of fertility. Quarterly Journal of Economics, 103, 1-25.

Becker, G. S., Murphy, K., \& Tamura, R. (1990). Human capital, fertility and economic growth. Journal of Political Economy, 98(5), 12-37.

Becker, S. O., Cinnirella, F., \& Woessmann, L. (2010). Education versus fertility: Evidence from before the demographic transition. Journal of Economic Growth, 15, 177-204.

Bhagwati, J. (1982). Directly unproductive profit-seeking activities. Journal of Political Economy, 90, 988-1002.

Birdsall, N. (1988). Economic approaches to population growth. In H. Chenery \& T. N. Srinivasan (Eds.), Handbook of development economics (Vol. 1). New York, NY: Elsevier Science.

Black, S. E., Devereux, P. J., \& Salvanes, K. G. (2005). The more the merrier? The effect of family composition on children's education. Quarterly Journal of Economics, 120, 669-700.

Bleakley, H., \& Lange, F. (2009). Chronic disease burden and the interaction of education, fertility, and growth. Review of Economics and Statistics, 91, 52-65. 
Bloom, D. E., \& Humair, S. (2010, April). Economic development in Nigeria: A demographic perspective. Presentation made to the Committee on African Studies, Harvard Africa Seminar, Cambridge, MA.

Cinyabuguma, M. (2011). Institutions, fertility, and growth. [Mimeo].

Da Silva, M. F. G., Garcia, F., \& Bandeira, A. C. (2000). How does corruption hurt growth? Evidences about the effects of corruption on factors productivity and per capita income (Working Paper). Sao Paulo, Brazil: Fundação Getulio Vargas.

De la Croix, D., \& Doepke, M. (2003). Inequality and growth: Why differential fertility matters. American Economic Review, 93, 10911113.

Djankov, S., La Porta, R., López-de-Silanes, F., \& Shleifer, A. (2002). The regulation of entry. Quarterly Journal of Economics, 117, 1-37.

Downey, D. B. (1995). When bigger is not better: Family size, parental resources, and children's educational performance. American Sociological Review, 60, 746-761.

Feng, Y., Kugler, J., \& Zak, P. (2000). The politics of fertility and economic development. International Studies Quarterly, 44, 667-693.

Fredriksson, P. G., \& Svensson, J. (2003). Political instability, corruption and policy formation: The case of environmental policy. Journal of Public Economics, 78(7-8), 1383-1405.

Galor, O., \& Weil, D. (1996). The gender gap, fertility and growth. American Economic Review, 86(3), 374-387.

Galor, O., \& Weil, D. (2000). Population, technology, and growth: From Malthusian stagnation to the demographic transition and beyond. American Economic Review, 90, 806-828.

Glaeser, E. L., La Porta, R., López-de-Silanes, F., \& Shleifer, A. (2004). Do institutions cause growth? Journal of Economic Growth, 9, 271-303.

Glomm, G., \& Ravikumar, B. (1994). Public investment in infrastructure in a simple growth model. Journal of Economic Dynamics and Control, 18(6), 1173-1187. 
Hall, R. E., \& Jones, C. I. (1999). Why do some countries produce so much more output per worker than others? Quarterly Journal of Economics, 114(1), 83-116.

Hanushek, E. A. (1992). The trade-off between child quantity and quality. Journal of Political Economy, 100, 84-117.

Hazan, M., \& Berdugo, B. (2002). Child labor, fertility and economic growth. Economic Journal, 112, 810-828.

Huntington, S. (1968). Political order in changing societies. New Haven, CT: Yale University Press.

Kalemli-Ozcan, S. (2003). A stochastic model of mortality, fertility, and human capital investment. Journal of Development Economics, 70, 103-118.

Kruger, A. O. (1974). The political economy of the rent-seeking society. American Economic Review, 64, 291-303.

La Porta, R., López-de-Silanes, F., Shleifer, A., \& Vishny, R. (1998). Law and finance. Journal of Political Economy, 106(6), 1113-1155.

Leff, N. H. (1964). Economic development through bureaucratic corruption. The American Behavioral Scientist, 8, 8-14.

Mauro, P. (1995). Corruption and growth. Quarterly Journal of Economics, 110, 681-712.

McEvedy, C., \& Jones, R. (1978). Atlas of world population history. New York, NY: Penguin.

Murphy, K., Shleifer, A., \& Vishny, R. (1991). The allocation of talent: Implications for growth. Quarterly Journal of Economics, 106, 503530 .

Murphy, K., Shleifer, A., \& Vishny, R. (1993). Why is rent-seeking so costly to growth? American Economic Review, 83, 409-414.

Murtin, F. (2009). On the demographic transition 1870-2000. [Mimeo].

Raut, L. K., \& Srinivasan, T. N. (1994). Dynamics of endogenous growth. Economic Theory, 4, 770-790. 
Rose-Ackerman, S. (1978). Corruption: A study in political economy. Waltham, MA: Academic Press.

Rosenzweig, M. R., \& Wolpin, K. I. (1980). Testing the quantity-quality model: The use of twins as a natural experiment. Econometrica, 48, 227-240.

Shleifer, A., \& Vishny, R. (1993). Corruption. Quarterly Journal of Economics, 108(3), 599-617.

Soares, R. (2005). Mortality reductions, educational attainment, and fertility choice. American Economic Review, 95, 580-601.

Tanzi, V., \& Davoodi, H. R. (1997). Corruption, public investment, and growth (Working Paper No. 97/139). Washington, DC: International Monetary Fund.

Transparency International. (n.d.). Corruption perceptions index. Retrieved from

http://www.transparency.org/policy_research/surveys_indices/cpi

Tullock, G. (1990). The economics of special privilege and rent-seeking. Boston, MA: Kluwer Academic Press.

Wang, C. (2005). Institutions, demographic transition, and industrial revolution: A unified theory. [Mimeo].

World Bank. (2010). World development indicators. New York, NY: Oxford University Press.

You, J., \& Khagram, S. (2005). A comparative study of inequality and corruption. American Sociological Review, 70, 136-157. 


\section{Appendix}

Table A1: First-Stage Regressions for IV Models

\begin{tabular}{|c|c|c|c|c|c|}
\hline & & & Depen & t variable & n corrup \\
\hline $\begin{array}{l}\text { Independent } \\
\text { Variable }\end{array}$ & 1 & 2 & 3 & 4 & 5 \\
\hline InGDPpc & $\begin{array}{l}-0.352^{* * *} \\
(0.029)\end{array}$ & $\begin{array}{l}-0.374^{* * *} \\
(0.030)\end{array}$ & $\begin{array}{l}-0.322^{* * *} \\
(0.028)\end{array}$ & $\begin{array}{l}-0.212^{* * *} \\
(0.032)\end{array}$ & $\begin{array}{l}-0.357^{* * *} \\
(0.029)\end{array}$ \\
\hline InSchooling & $\begin{array}{l}0.0076 \\
(0.018)\end{array}$ & $\begin{array}{l}-0.009 \\
(0.019)\end{array}$ & $\begin{array}{l}-0.035^{*} \\
(0.019)\end{array}$ & $\begin{array}{l}-0.017 \\
(0.018)\end{array}$ & $\begin{array}{l}-0.0002 \\
(0.020)\end{array}$ \\
\hline Catholic & $\begin{array}{l}0.0019^{* * *} \\
(0.0006)\end{array}$ & $\begin{array}{l}0.0018^{* * *} \\
(0.0006)\end{array}$ & $\begin{array}{l}0.0011^{*} \\
(0.0006)\end{array}$ & $\begin{array}{l}0.0009 \\
(0.0006)\end{array}$ & $\begin{array}{l}0.0018^{* * *} \\
(0.0006)\end{array}$ \\
\hline Muslim & $\begin{array}{l}0.0006 \\
(0.0007)\end{array}$ & $\begin{array}{l}0.0005 \\
(0.0007)\end{array}$ & $\begin{array}{l}0.0004 \\
(0.0007)\end{array}$ & $\begin{array}{l}0.0001 \\
(0.0007)\end{array}$ & $\begin{array}{l}0.0006 \\
(0.0007)\end{array}$ \\
\hline Protestant & $\begin{array}{l}-0.005^{* * *} \\
(0.001)\end{array}$ & $\begin{array}{l}-0.006^{* * *} \\
(0.001)\end{array}$ & $\begin{array}{l}0.0075^{* * *} \\
(0.001)\end{array}$ & $\begin{array}{l}0.0083^{* * *} \\
(0.001)\end{array}$ & $\begin{array}{l}0.005^{* * *} \\
(0.001)\end{array}$ \\
\hline Latitude & $\begin{array}{l}1.811^{* * *} \\
(0.513)\end{array}$ & $\begin{array}{l}1.748^{* * *} \\
(0.324)\end{array}$ & $\begin{array}{l}1.649 * * * \\
(0.315)\end{array}$ & $\begin{array}{l}1.719^{* * *} \\
(0.310)\end{array}$ & $\begin{array}{l}1.789^{* * *} \\
(0.325)\end{array}$ \\
\hline Latitude sq. & $\begin{array}{l}-4.658^{* * *} \\
(0.513)\end{array}$ & $\begin{array}{l}-4.473^{* * *} \\
(0.515)\end{array}$ & $\begin{array}{l}-3.847^{* * *} \\
(0.510)\end{array}$ & $\begin{array}{l}-3.710^{* * *} \\
(0.502)\end{array}$ & $\begin{array}{l}-4.637^{* * *} \\
(0.514)\end{array}$ \\
\hline LegalBritish & $\begin{array}{l}-0.0169 \\
(0.066)\end{array}$ & $\begin{array}{l}-0.0188 \\
(0.065)\end{array}$ & $\begin{array}{l}-0.035 \\
(0.063)\end{array}$ & $\begin{array}{l}-0.046 \\
(0.063)\end{array}$ & $\begin{array}{l}-0.015 \\
(0.065)\end{array}$ \\
\hline LegalFrench & $\begin{array}{l}0.149 \\
(0.075)\end{array}$ & $\begin{array}{l}0.145 \\
(0.074)\end{array}$ & $\begin{array}{l}0.076 \\
(0.073)\end{array}$ & $\begin{array}{l}0.017 \\
(0.073)\end{array}$ & $\begin{array}{l}0.015 \\
(0.074)\end{array}$ \\
\hline DLowInc & & $\begin{array}{l}-0.145^{* * *} \\
(0.053)\end{array}$ & & & \\
\hline DMdlInc & & & $\begin{array}{l}0.263^{* * *} \\
(0.028)\end{array}$ & & \\
\hline DHighInc & & & & $\begin{array}{l}-0.528^{* * *} \\
(0.063)\end{array}$ & \\
\hline DSSA & & & & & $\begin{array}{l}-0.055 \\
(0.049)\end{array}$ \\
\hline Constant & $\begin{array}{l}4.335^{* * *} \\
(0.218)\end{array}$ & $\begin{array}{l}4.580^{* * * *} \\
(0.235)\end{array}$ & $\begin{array}{l}4.099^{* * *} \\
(0.214)\end{array}$ & $\begin{array}{l}3.494^{* * *} \\
(0.231)\end{array}$ & $\begin{array}{l}4.406^{* * *} \\
(0.228)\end{array}$ \\
\hline $\begin{array}{l}\text { No. of } \\
\text { observations }\end{array}$ & 689 & 689 & 689 & 689 & 689 \\
\hline Adjusted $\mathrm{R}$ & 0.76 & 0.76 & 0.77 & 0.78 & 0.76 \\
\hline
\end{tabular}

Notes: The table presents estimates of model's coefficients via first-stage IV regression model. Standard errors are given in parentheses. Asterisks ${ }^{*},{ }^{* *}$, and ${ }^{* * *}$ indicate significance at 10, 5, and 1 percent levels, respectively. 


\section{Appendix}

\section{Definition of Variables used in the empirical model:}

1. $\ln \mathrm{GDPpc}=\log$ GDP per capita.

2. $\operatorname{lnS}$ chooling $=\log$ completed secondary schooling.

3. Catholic $=$ percentage of people who are Catholic.

4. Muslim = percentage of people who are Muslim.

5. Protestant $=$ percentage of people who are Protestant.

6. LegalFrench $=$ French legal origin .

7. LegalBritish $=$ British legal origin

8. DLowInc $=$ dummy variable for low-income countries.

9. DMdlInc = dummy variable for middle-income countries.

10. DHighInc $=$ dummy variable for high-income countries.

11. CorXLowInc $=$ corruption times dummy variable for low-income countries.

12. CorXMdlInc = corruption times dummy variable for middle-income countries.

13. CorXHighInc $=$ corruption times dummy variable for high-income countries.

14. DSSA = dummy variable for sub-Saharan African countries.

15. $\operatorname{lnCorruption}=\log$ of corruption.

16. Latitude $=$ latitude.

17. Latitude sq. = latitude squared. 